\title{
The research on well pattern adjustment strategy of PL oilfield
}

\author{
Wensheng Zhou ${ }^{1,2, a}$, Yang Feng ${ }^{3, b}$, Lingyun Zheng ${ }^{3, b}$ and Jicheng Zhang ${ }^{3, b}$
}

\author{
${ }^{1}$ State Key Laboratory of Offshore Oil Exploitation, Beijing, China, 100027 \\ ${ }^{2}$ Cnooc (China) co., LTD., Beijing research center, Beijing, China, 100027 \\ ${ }^{3}$ College of Petroleum Engineering, Northeast Petroleum University. Daqing City, \\ Heilongjiang Province, 163318 \\ a zhouwsh@cnooc.com.cn, ${ }^{b} 13069659713 @ 163 . c o m,{ }^{b}$ zhengly1993@163.com, \\ bzhangjc777@163.com
}

Keywords: reasonable well spacing; pseudo oil production rate; recovery factor; numerical simulation model.

Abstract: PL oilfield adopts commingled production with big intervals, which causes serious conflict among layers, so layer system and well pattern adjustment of later stage is required, at this time we will need to determine the scope of the reasonable well spacing. Three main pay formations of PL oilfield has a big difference in crude oil viscosity, which also have different reservoir property. On the basis of the analysis of actual production condition, numerical simulation model is set up separately for each reservoir. Results showed that the ultimate recovery degree under different well spacing were similar with the present condition of mining. But with the increase of well spacing, the increased amplitude of the recovery degree becomes smaller than before, the time to achieve the ultimate recovery increases. In order to further determine the scope of the rational well spacing, the concept of pseudo oil production rate is introduced. On the basis of the actual oil production rate, determine the scope of the reasonable well spacing of each reservoir on the condition that the pseudo oil production rate was $2 \%$, and analyze its reasons. Considering the practical mining conditions and the drilling cost, the layer combination and well pattern of PL oilfield has been adjusted, its development effect and economic benefits are predicted through the numerical simulation model. The research for PL oilfield late development adjustment provides a certain theoretical basis, which also has guiding significance for other oilfields to improve development effect.

\section{Introduction}

Determining reasonable injection-production well spacing is a very important factor to consider when well pattern adjustment at later stage of oilfield is needed and how to improve the oilfield development effect. If the injection-production well spacing is too small, more new well is needed, which causes big well spacing density and increases the economic costs. As the drilling cost and oil price fluctuate, it will increase the risk of oilfield development. If injection-production well spacing is too large, the pressure cost will increase between the injection well and the production well. The water driving sweep efficiency decreases so that water flooding effect is poor for strong heterogeneity reservoirs. Therefore we need to determine reasonable well spacing so that oilfield can obtain the best development effect and economic benefit [1,2,3,4,5]. At present, the reasonable injection-production well spacing mostly aims at low permeability reservoirs. Based on its main contradictions, mainly consider start-up pressure gradient, combine with the technical limit well spacing and the economic reasonable well spacing, and then determine the reasonable well spacing 
[5-8]. But for high permeability conventional reservoir, the main research is about its oil production rate, water driving control degree, the ultimate recovery efficiency and so on. Due to the good displacement relationship between the injection well and the production well under different well spacing, the research about rational injection-production well spacing for high permeable reservoir is less. Well spacing do not have a significant influence on the ultimate recovery of high permeability reservoir. Therefore it is difficult to determine the scope of the reasonable well spacing through the ultimate recovery degree $[6,7,8,9,10,11,12]$.

In order to determine the scope of reasonable well spacing like such reservoir, provide certain theoretical basis for this kind of reservoir development, this paper proposes a new method of research and application of numerical simulation model. By introducing the concept of pseudo oil production rate, determine reasonable well spacing under different pseudo oil production rate. On this basis of this, well pattern adjustment scheme of PL oilfield formation is set up, and numerical simulation predicting results show that good development effect can be obtained.

\section{The brief introduction of oilfield}

Geological characteristics. PL oilfield is located in the central and southern area of BH sea, from top to bottom, it contains group P of neogene, group MHZ of neogene and group GT of neogene, group DY of paleogene, group SHJ of paleogene, group KD of paleogene and cretaceous strata. Group lower MHZ and group GT is the main pay production layer of the oilfield. Group lower MHZ is mainly mudstone at the top, with thin layer sandstone. At the medium and bottom part, it exists sand shale interbed. Group GT formation is mainly fine-grained sandstone, fine sandstone, with thin layers of mudstone. The main pay production layers is divided into 5 sections at the group lower MHZ, namely from oil section L00 to L40. Upper Group GT is divided into three sections, namely from oil group L50 to L70, group lower GT is divided into five sections, namely from oil group L80 to L120., The porosity of the group lower MHZ ranges from $23.5 \%$ to $34.7 \%$, the average value is $28 \%$; Permeability ranges mainly from $17 \mathrm{mD}$ to $2200 \mathrm{mD}$, which is generally greater than $50 \mathrm{mD}$, the average value is $1627 \mathrm{md}$. Group MHZ has high permeability and high porosity. The porosity of the group upper GT ranges from $20.6 \%$ to $32.6 \%$, the average value is $27 \%$; Permeability ranges mainly from $15 \mathrm{mD}$ to $2330 \mathrm{mD}$, which is generally greater than $50 \mathrm{mD}$, the average value is $1555 \mathrm{mD}$. Group GT has high permeability and high porosity. The porosity of the group lower GT ranges from $18.9 \%$ to $30.0 \%$, the average value is $23.3 \%$; Permeability ranges mainly from $18 \mathrm{mD}$ to $5900 \mathrm{mD}$, it ranges mainly from $50 \mathrm{mD}$ to $1000 \mathrm{mD}$, the average value is 936md. It has high permeability and medium-high porosity.

The brief development situation. PL oilfield adopts inverted nine spot flooding pattern to do the water driving development, it is mainly about commingled production with big intervals, layered water injection is a complementary way of water injection. Group MHZ has high crude oil viscosity, it is from $78.7 \mathrm{mPa}$ s to $262.8 \mathrm{mPa}$ s, which belongs to the category of heavy oil, The oil viscosity of group GT is less than 50mpa $\bullet$ s. Group GT belongs to the conventional crude oil, the difference of crude oil properties is obvious; Production dynamic data shows that group MHZ has a lower capacity, Interlayer interference is bigger when group MHZ is combined with group GT. The contribution of Group MHZ is small, so take a set of formation to do the development, the main production interval is group GT, some developing well use the bottom of group MHZ. Due to imperfect injection-production system, the formation is void and serious, it is essential to adjust well pattern. 


\section{Reasonable injection-production well spacing}

Setting up the model. Using numerical simulation software of Eclipse, set up the single numerical simulation model for the group lower MHZ, the group upper GT and the group lower GT respectively, the grid size of the model is $5 \mathrm{~m} \times 5 \mathrm{~m}$, the injection-production well spacing for design is $125 \mathrm{~m}, 150 \mathrm{~m}, 175 \mathrm{~m}, 200 \mathrm{~m}$ and $225 \mathrm{~m}, 250 \mathrm{~m}, 275 \mathrm{~m}, 300 \mathrm{~m}, 325 \mathrm{~m}$ and $350 \mathrm{~m}$. A numerical simulation model is shown in Fig. 1. Well P1 is a production well, well I1 is a injection well, coordinates of oil and water wells under various well spacing grid number are shown in Table 1.

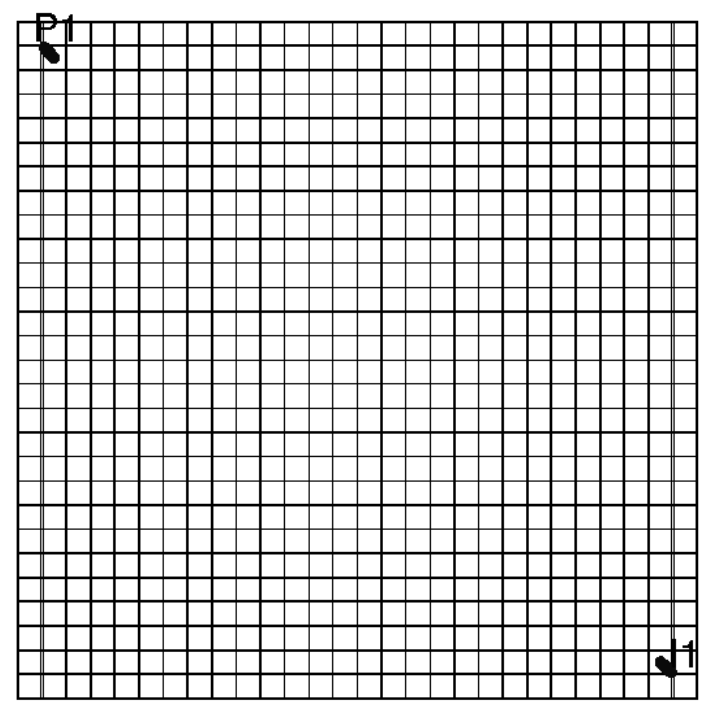

Fig. 1 a model for the numerical simulation

Table 1 designning table of numerical simulation model

\begin{tabular}{c|c|c}
\hline $\begin{array}{c}\text { Well spacing } \\
{[\mathrm{m}]}\end{array}$ & $\begin{array}{c}\text { coordinates of oil well } \\
(\mathrm{x}, \mathrm{y})\end{array}$ & $\begin{array}{c}\text { coordinates of water well } \\
(\mathrm{x}, \mathrm{y})\end{array}$ \\
\hline 125 & $(2,2)$ & $(20,20)$ \\
\hline 150 & $(2,2)$ & $(23,23)$ \\
\hline 175 & $(2,2)$ & $(27,27)$ \\
\hline 200 & $(2,2)$ & $(30,30)$ \\
\hline 225 & $(2,2)$ & $(34,34)$ \\
\hline 250 & $(2,2)$ & $(41,41)$ \\
\hline 275 & $(2,2)$ & $(44,44)$ \\
\hline 300 & $(2,2)$ & $(48,48)$ \\
\hline 325 & $(2,2)$ & $(51,51)$ \\
\hline 350 & $(2,2)$ &
\end{tabular}

The average value such as permeability, thickness, porosity, water saturation of each layer is set as the corresponding value of Numerical simulation model. Analyze the actual mining condition of each layer, and then according to the actual water injection intensity and liquid producing intensity, determine respectively the water injection and liquid producing capacity of the numerical simulation model, which is shown in Table 2. 
Table 2 the parameter list of numerical simulation model

\begin{tabular}{c|c|c|c|c|c|c}
\hline Layer & $\begin{array}{c}\text { porosity } \\
{[\%]}\end{array}$ & Permeability[mD] & $\begin{array}{c}\text { Water } \\
\text { saturation } \\
{[\%]}\end{array}$ & $\begin{array}{c}\text { Thickness } \\
{[\mathrm{m}]}\end{array}$ & $\begin{array}{c}\text { Injection } \\
\text { capacity } \\
\text { per day } \\
{\left[\mathrm{m}^{3} / \mathrm{d}\right]}\end{array}$ & $\begin{array}{c}\text { Liquid } \\
\text { output } \\
\text { per day } \\
{\left[\mathrm{m}^{3} / \mathrm{d}\right]}\end{array}$ \\
\hline $\begin{array}{c}\text { Group lower } \\
\text { MHZ }\end{array}$ & 28 & 1627 & 29 & 2.5 & 12.2 & 12.2 \\
\hline $\begin{array}{c}\text { Group Upper } \\
\text { GT }\end{array}$ & 27 & 1555 & 32 & 2.5 & 23.6 & 23.6 \\
\hline $\begin{array}{c}\text { group lower } \\
\text { GT }\end{array}$ & 23 & 936 & 33 & 2 & 10.9 & 10.9 \\
\hline
\end{tabular}

According to the characteristic of oil viscosity and permeability from group lower MHZ, group upper GT and group lower GT, draw respectively permeability ratio curve of every layer, which is shown in Fig. 2.

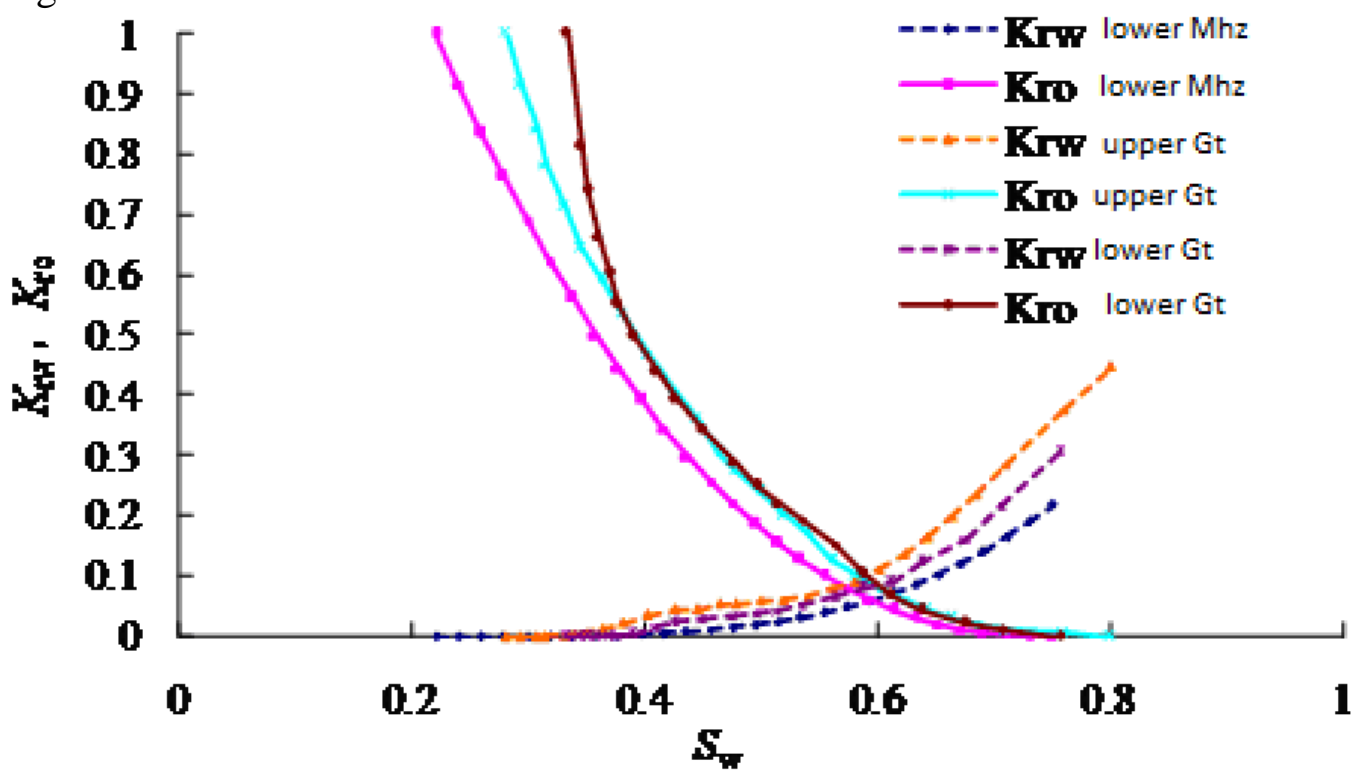

Fig. 2 permeability ratio curve of every layer

Forecast result. By the calculation of the above model, under the same scheme (which refers the same type reservoir), the time to achieve ultimate recovery degree is different, which could be seen in Table 3. And the relationship between recovery degree and time with different interval and different well spacing is drawed respectively, which is shown from Fig. 3 to Fig. 5.

Table 3 the calculating results of numerical simulation model

\begin{tabular}{c|c|c|c}
\hline \multirow{2}{*}{ layer } & $\begin{array}{c}\text { Well spacing } \\
{[\mathrm{m}]}\end{array}$ & $\begin{array}{c}\text { Ultimate recovery } \\
{[\%]}\end{array}$ & $\begin{array}{c}\text { Production age limit } \\
{[\text { [year] }}\end{array}$ \\
\hline \multirow{5}{*}{ group MHZ } & 125 & 35.88 & 4.16 \\
\cline { 2 - 4 } & 150 & 35.94 & 5.35 \\
\cline { 2 - 4 } & 175 & 36.04 & 7.21 \\
\cline { 2 - 4 } & 200 & 36.11 & 9.25 \\
\cline { 2 - 4 } & 225 & 36.19 & 11.80 \\
\cline { 2 - 4 } & 250 & 36.18 & 13.13 \\
\cline { 2 - 4 } & 275 & 36.24 & 16.88 \\
\cline { 2 - 4 } & 300 & 36.27 & 22.87 \\
\hline
\end{tabular}




\begin{tabular}{|c|c|c|c|}
\hline layer & $\begin{array}{l}\text { Well spacing } \\
{[\mathrm{m}]}\end{array}$ & $\begin{array}{c}\text { Ultimate recovery } \\
{[\%]}\end{array}$ & $\begin{array}{c}\text { Production age limit } \\
\text { [year] }\end{array}$ \\
\hline & 350 & 36.30 & 25.79 \\
\hline \multirow{10}{*}{ group upper GT } & 125 & 49.07 & 2.22 \\
\hline & 150 & 49.07 & 2.47 \\
\hline & 175 & 49.11 & 3.73 \\
\hline & 200 & 49.19 & 4.58 \\
\hline & 225 & 49.21 & 5.77 \\
\hline & 250 & 49.27 & 6.79 \\
\hline & 275 & 49.30 & 8.23 \\
\hline & 300 & 49.32 & 9.42 \\
\hline & 325 & 49.33 & 11.12 \\
\hline & 350 & 49.37 & 12.55 \\
\hline \multirow{10}{*}{ Group lower GT } & 125 & 51.36 & 2.97 \\
\hline & 150 & 51.46 & 3.82 \\
\hline & 175 & 51.60 & 5.18 \\
\hline & 200 & 51.64 & 6.28 \\
\hline & 225 & 51.70 & 7.98 \\
\hline & 250 & 51.77 & 9.42 \\
\hline & 275 & 51.80 & 11.46 \\
\hline & 300 & 51.82 & 13.13 \\
\hline & 325 & 51.85 & 15.55 \\
\hline & 350 & 51.86 & 17.47 \\
\hline
\end{tabular}

It can be seen from the table that in the same interval, the value of ultimate recovery degree is alike with different well spacing, but the production age limits has big differences. It costs shorter time to achieve ultimate recovery degree when well spacing gets smaller.

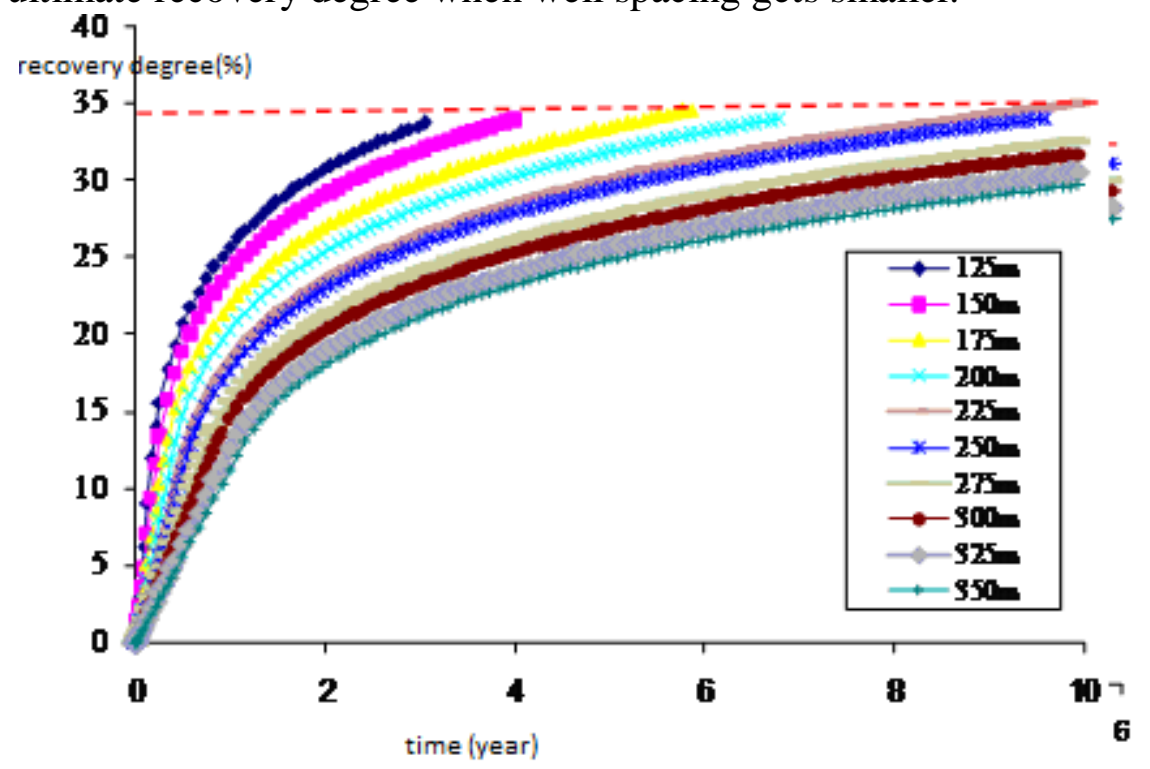

Fig. 3 the relationship between recovery degree and time with different well spacing on the lower MHZ 


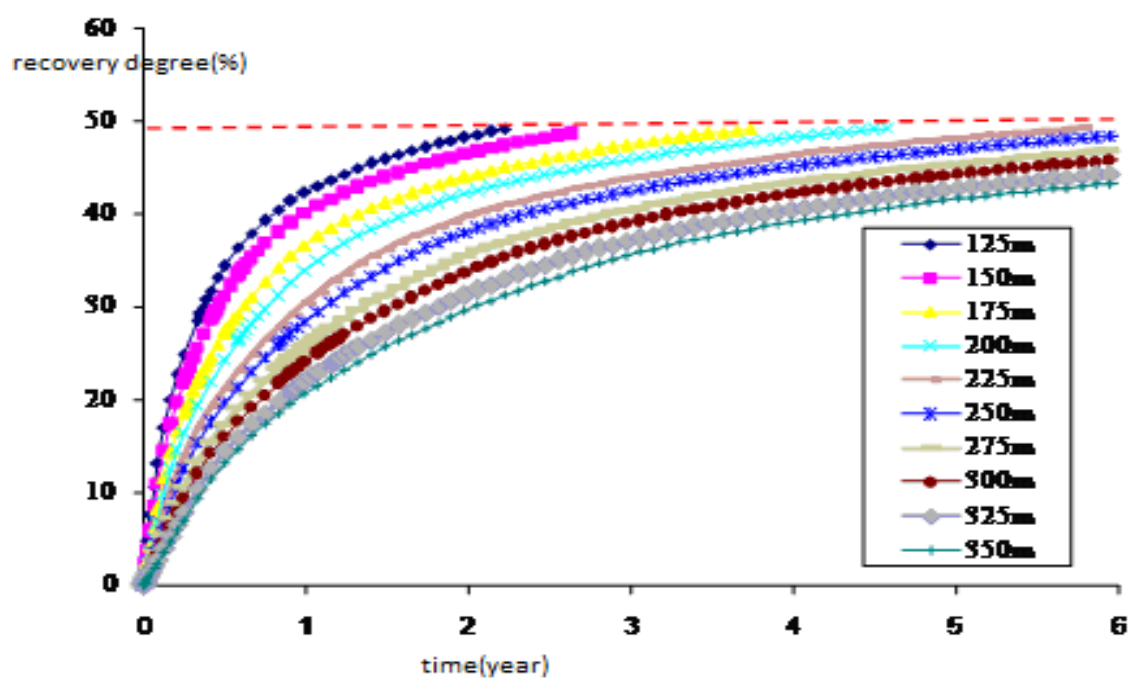

Fig. 4 the relationship between recovery degree and time with different well spacing on the group

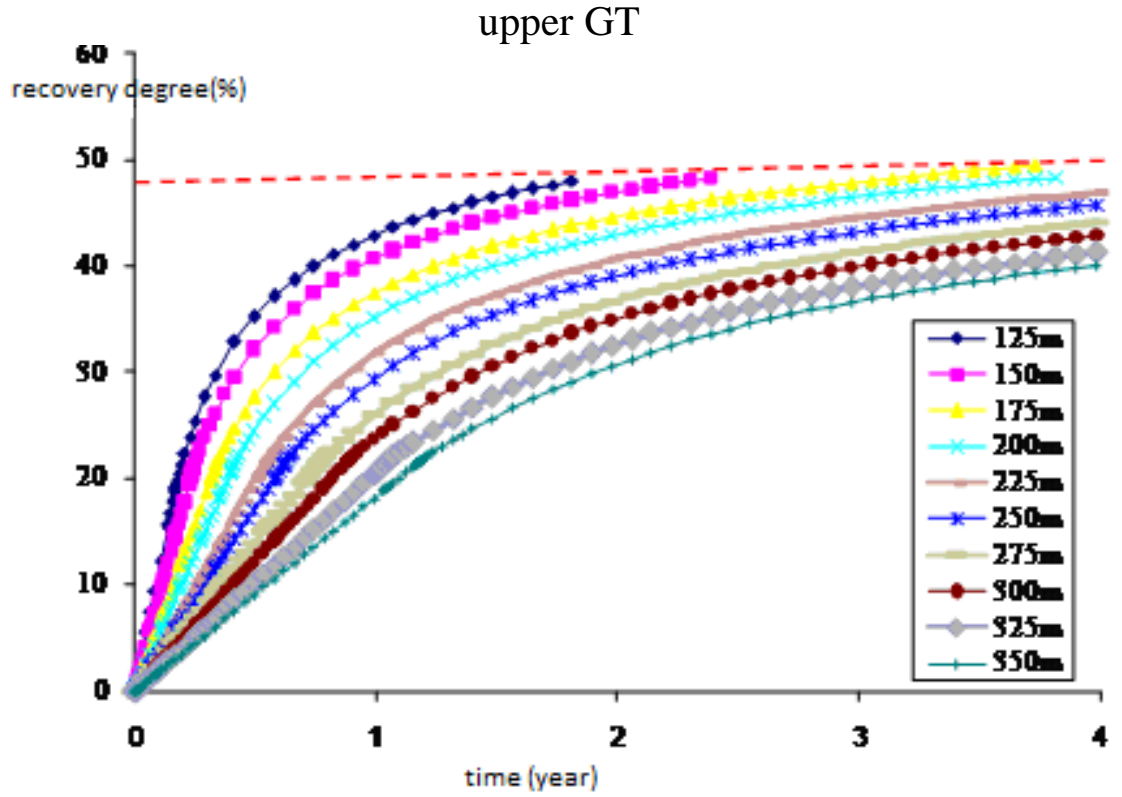

Fig. 5 the relationship between recovery degree and time with different well spacing on the group lower GT

From the relationship curve between recovery degree and time, it can be seen that with the increase of well spacing, recovery degree increase with the increase of time, and later the amplitude which recovery degree increased decreases. But the smaller well spacing, the shorter fixed time to reach the maximum recovery degree. But we can not determine the scope of the reasonable well spacing.

Determine pseudo oil production rate. In order to determine reasonable well spacing scope of each reservoir, guide the adjustment of oilfield later stage layer system and well pattern, improve oilfield development effect, the concept of pseudo oil production rate is introduced. Because the actual block is not a simple and ideal situation which a injection well is corresponding to a production well, the actual area is certain, the change of well spacing can lead to the change of the well number on unit area, which also refers the change of well spacing density. It can be seen in Fig. 6 and Fig. 7. 


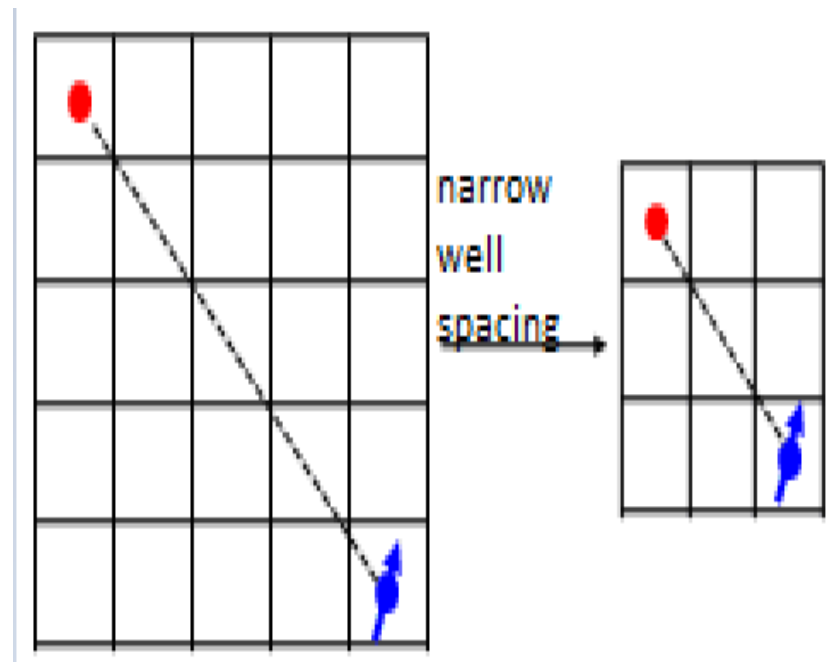

Fig. 6 reduce the spacing of the numerical simulation model

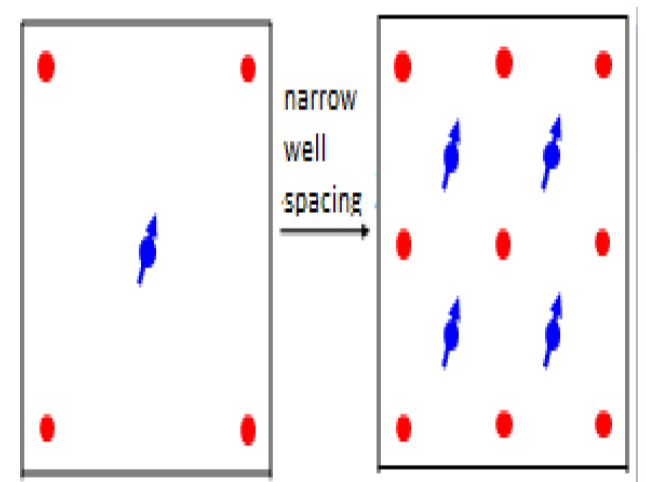

Fig. 7 reduce the spacing of the actual reservoir

In order to have comparability in the mining condition of different well spacing for Numerical simulation model, average annual oil production rate under different well spacing in the numerical simulation model is equivalent to the annual oil production rate from Wells unit area. Annual oil production rate from Wells unit area is called to pseudo oil production rate. The specific calculation method is as follows:

$$
\text { pseudo oil production rate }=\text { average annual oil production rate per well } \times \frac{1}{(\text { wellspacing } / 100)^{2}} \times 100 \% \text {. }
$$

Among them:

$$
\text { Average annual oil production rate per well }=\frac{\text { recovery }}{\text { time }(\text { year })} \text {. }
$$

The sum of well unit area $=\frac{1}{(\text { well spacing/100 })^{2}}$.

The reasonable well spacing scope of every layers for PL oilfield. According to the calculation results of numerical simulation model, combined with the definition of pseudo oil production rate, draw the relationship curve of every oil layer between pseudo oil production rate 
and well spacing, which is shown in Fig. 8. The oil layer will correspond to different scope of reasonable well spacing under different pseudo production rate. According to the actual injection-production condition of PL oilfield, determine the actual oil production rate is about $1.1 \%$, oil production rate is small. In order to adjust the development effect of later stage later stage, the scope of the reasonable spacing of different reservoir under the condition that pseudo production rate was $2 \%$ is determined.

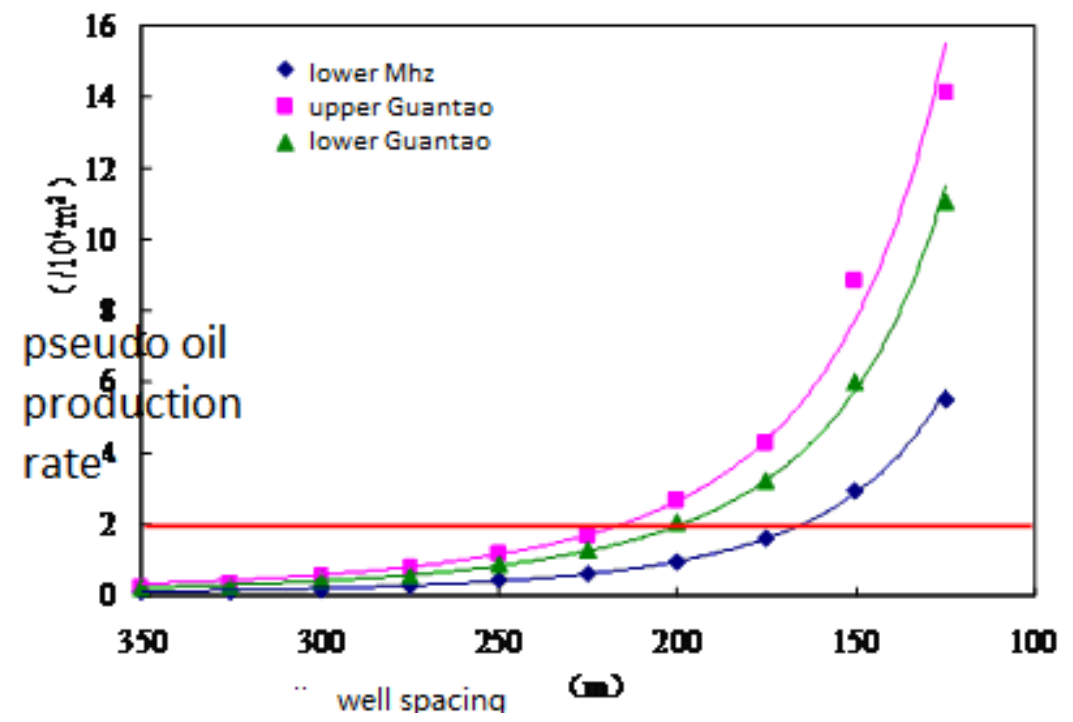

Fig. 8 pseudo oil production rate with different well spacing from different layers

It can be seen from the diagram that with the decrease of well spacing, pseudo oil production rate increases and the increased amplitude increased, which the increased amplitude of group GT increased greatest. When the pseudo oil production rate is $2 \%$, the well spacing from group lower MHZ is about $160 \mathrm{~m}$, its reasonable well spacing range is from $150 \mathrm{~m}$ to $200 \mathrm{~m}$. The well spacing from group upper GT is about $210 \mathrm{~m}$, its reasonable well spacing range is from $200 \mathrm{~m}$ to $250 \mathrm{~m}$. The well spacing from group lower GT is about $200 \mathrm{~m}$, its reasonable well spacing range is from $175 \mathrm{~m}$ to $225 \mathrm{~m}$.

Thus it can be seen that the well spacing range of the bottom of group MHZ is less than that of group GT. This is because that the group MHZ has a large crude oil viscosity, oil/water viscosity ratio is large, in order to improve the degree of washing, increase water injection sweep efficiency, it is essential to narrow well spacing. And group lower GT and group upper GT do not have a big difference in crude oil viscosity. Due to the permeability of group lower GT is poor than that of group upper GT, fluid start-up pressure is higher, so we need to narrow well spacing. And the well spacing range of group lower GT is less than that of group upper GT.

By the curvilinear regression between pseudo oil production rate and well spacing from different layers, the regression formulas between pseudo oil production rate and well spacing from the different layers is shown in Table 4.

Table 4 the regression formula between pseudo oil production rate and well spacing with different layers

\begin{tabular}{c|c}
\hline layer & the regression formula \\
\hline Group lower MHZ & $y=1 \times 10^{9} x^{-3.75}$ \\
\hline Group upper GT & $y=8 \times 10^{8} x^{-3.74}$ \\
\hline Group lower GT & $y=5 \times 10^{8} x^{-3.79}$ \\
\hline
\end{tabular}


Through the above analysis, the regression formula between pseudo oil production rate and well spacing can be shown as follow:

$$
y=\alpha x^{-\beta} .
$$

Where $\mathrm{y}$ is pseudo oil production rate, $/ 10^{4} \mathrm{~m}, \mathrm{x}$ is well spacing, $\mathrm{m}, \alpha$ is coefficient related to geological parameters and production status, $\beta$ is coefficient related to geological parameters and production status.

So the scope of reasonable well spacing can be determined in the actual production rate through the above regression formula. It provides a simple and effective method and theoretical basis for the adjustment of reservoir development.

\section{Formation well pattern adjustment scheme and effect}

On the basis of reasonable well spacing scope, consider the actual drilling conditions of oilfield and the cost, the AA strategy of formation well pattern adjustment for PL oilfield is determined, which is shown in Fig. 9.

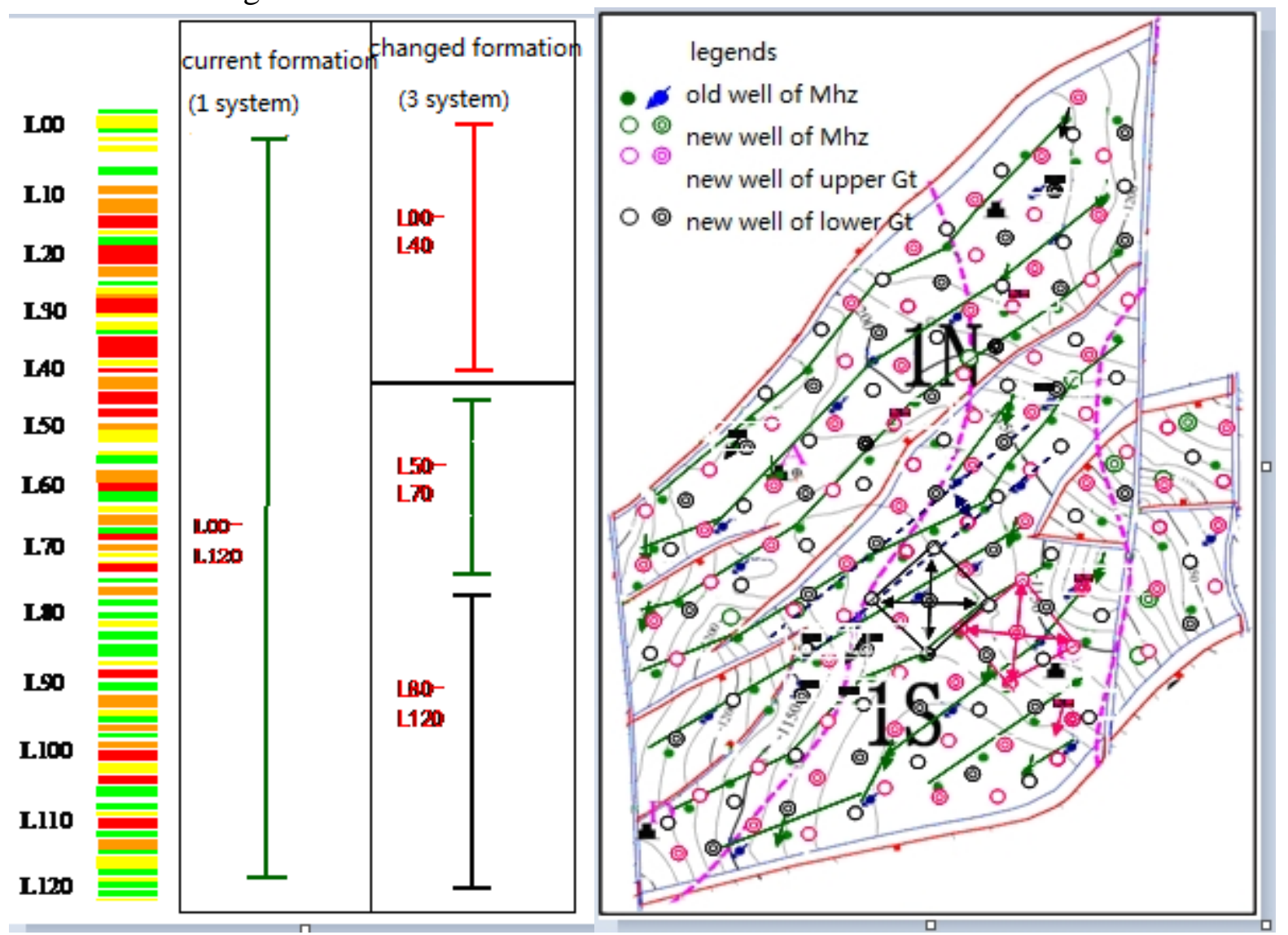

Fig. 9 the method of layer system combination and well pattern adjustment

The group MHZ and group GT are divided into three layer systems to do the synchronizing production, the specific design scheme is as follows: The layer system of group MHZ gives priority to new drilling, and combine with some old well, formed a set of five point area of $300 \mathrm{~m}$ spacing pattern to develop. Group upper GT uses the old well to transfer the original area of the nine between well pattern of injection production Wells on the edge of the well, and drill some new Wells, and formed $300 \mathrm{~m}$ spacing of transverse linear pattern mining. At the same time, the original Wells which perforated group MHZ and group lower GT is closed, group upper GT Is put into production. Group lower GT gives priority to new drilling, and combined with some old well, 
formed a set of five point area of 300m spacing pattern to exploit group lower GT. The condition of production proration and injection proration from every layers is shown in Table 5.

Table 5 The condition of production proration and injection proration from every layers

\begin{tabular}{|c|c|c|c|c|c|c|c|c|}
\hline \multirow{3}{*}{ Layer } & \multicolumn{4}{|c|}{ The south area } & \multicolumn{4}{|c|}{ The north area } \\
\hline & \multicolumn{2}{|c|}{ injection rate per day } & \multicolumn{2}{|c|}{$\begin{array}{l}\text { Liquid output per } \\
\text { day }\end{array}$} & \multicolumn{2}{|c|}{ injection rate per day } & \multicolumn{2}{|c|}{$\begin{array}{l}\text { Liquid output per } \\
\text { day }\end{array}$} \\
\hline & $\begin{array}{l}\text { Total } \\
{\left[\mathrm{m}^{3}\right]}\end{array}$ & $\begin{array}{c}\text { Average } \\
\text { per well } \\
{\left[\mathrm{m}^{3}\right]}\end{array}$ & $\begin{array}{l}\text { total } \\
{\left[\mathrm{m}^{3}\right]}\end{array}$ & $\begin{array}{c}\text { Average } \\
\text { per well } \\
{\left[\mathrm{m}^{3}\right]}\end{array}$ & $\begin{array}{l}\text { total } \\
{\left[\mathrm{m}^{3}\right]}\end{array}$ & $\begin{array}{c}\text { Average } \\
\text { per well } \\
{\left[\mathrm{m}^{3}\right]}\end{array}$ & $\begin{array}{l}\text { total } \\
{\left[\mathrm{m}^{3}\right]}\end{array}$ & $\begin{array}{c}\text { Average } \\
\text { per well } \\
{\left[\mathrm{m}^{3}\right]}\end{array}$ \\
\hline $\begin{array}{l}\text { Group } \\
\text { lower } \\
\text { MHZ }\end{array}$ & 403.32 & 16.13 & 403.32 & 14.40 & 262.42 & 17.49 & 262.42 & 17.49 \\
\hline $\begin{array}{c}\text { Group } \\
\text { upper } \\
\text { GT }\end{array}$ & 5331.62 & 242.35 & 5331.62 & 166.61 & 6010.83 & 500.90 & 6010.83 & 300.54 \\
\hline $\begin{array}{l}\text { Group } \\
\text { lower } \\
\text { GT }\end{array}$ & 10676.12 & 533.81 & 10676.12 & 395.41 & 10919.54 & 727.97 & 10919.54 & 606.64 \\
\hline
\end{tabular}

The development effect forecast of formation well pattern adjustment scheme is completed, the result is shown in Fig. 10 and Fig. 11.

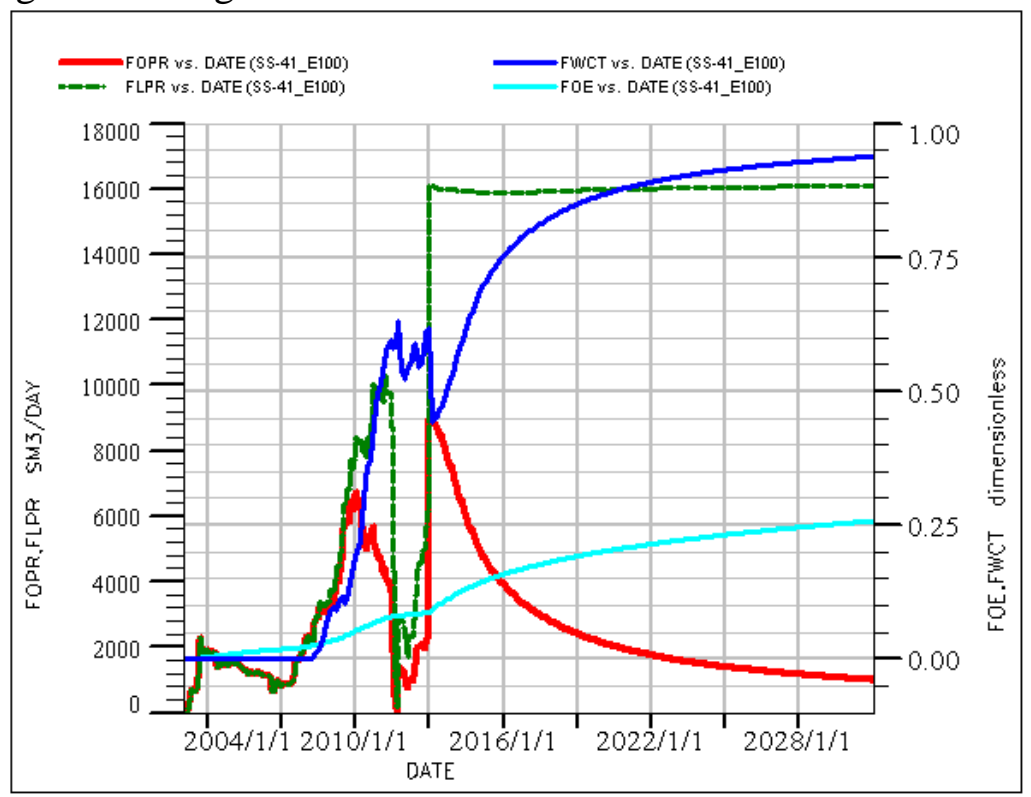

Fig. 10 the predicting curve of the south area 


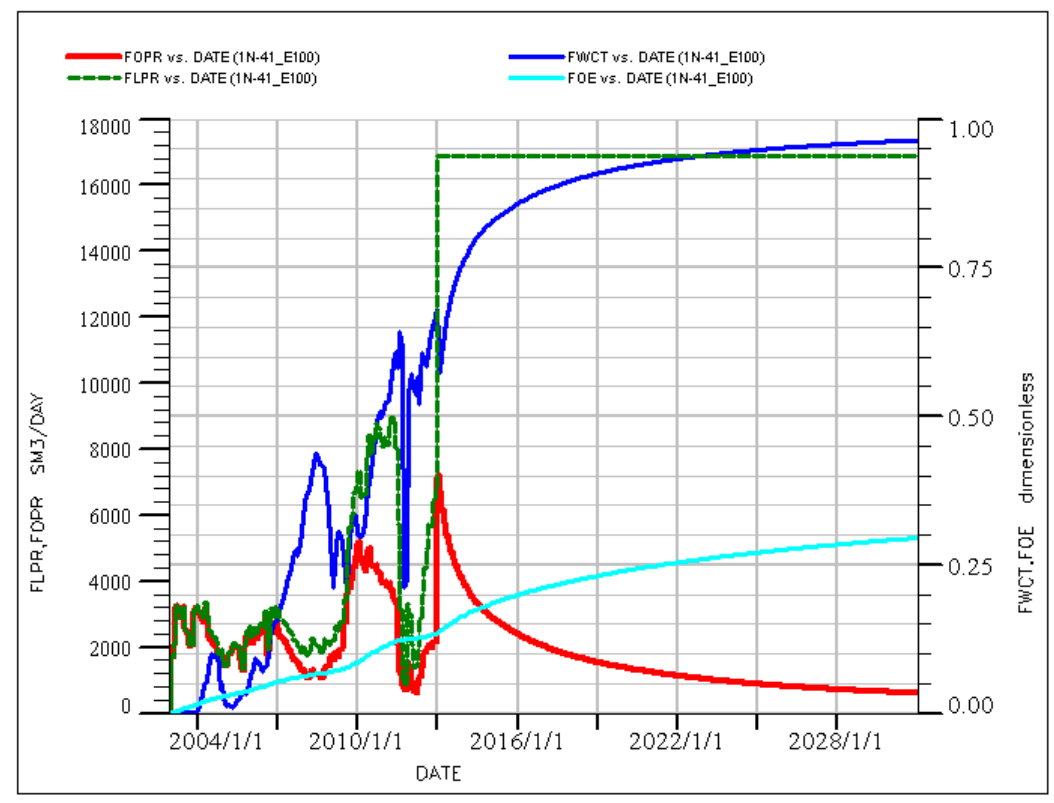

Fig. 11 the predicting curve of the north area

It can be seen from Fig. 10 and Fig. 11 that through constant liquid production, oil production declined year by year, it drops smaller at the late stage, the amplitude which recovery degree rises gradually becomes smaller, but the increased amplitude of the base plan is large. By the end of 2030, recovery degree of the south area is $26.3 \%$, which is increased by $9.2 \%$ compared with the base plan, recovery degree of the north area was $29.5 \%$, which is increased by $5.9 \%$ compared with the base plan.

To calculate the economic benefits under different drilling cost and the unit price of crude oil (economic benefit $=$ the unit price of crude oil $\times$ recovery degree $\times$ crude oil reserves - the drilling costs), which is shown in Table 6. Scheme in the selection of single well cost and unit price of crude oil can be obtained certain economic benefits.

Table 6 Economic benefit calculation table

\begin{tabular}{|c|c|c|c|c|c|}
\hline area & $\begin{array}{c}\text { recovery } \\
\text { degree[\%] }\end{array}$ & $\begin{array}{c}\text { Cost per well } \\
\text { [ten } \\
\text { thousand } \\
\text { yuan] }\end{array}$ & $\begin{array}{l}\text { Crude oil price } \\
\text { [ten thousand } \\
\text { yuan } / \mathrm{m}^{3} \text { ] }\end{array}$ & $\begin{array}{c}\text { benefit } \\
\text { [hundred } \\
\text { million yuan] }\end{array}$ & $\begin{array}{l}\text { oil increased output } \\
\text { [ten thousand } \mathrm{m}^{3} \text { per } \\
\text { well] }\end{array}$ \\
\hline \multirow{4}{*}{ South area } & \multirow{4}{*}{26.3} & \multirow{2}{*}{10000} & 0.3 & 173.45 & \multirow{4}{*}{9.42} \\
\hline & & & 0.6 & 441.89 & \\
\hline & & \multirow{2}{*}{5000} & 0.3 & 220.95 & \\
\hline & & & 0.6 & 489.39 & \\
\hline \multirow{4}{*}{ North area } & \multirow{4}{*}{29.5} & \multirow{2}{*}{10000} & 0.3 & 52.97 & \multirow{4}{*}{6.23} \\
\hline & & & 0.6 & 166.94 & \\
\hline & & \multirow{2}{*}{5000} & 0.3 & 83.47 & \\
\hline & & & 0.6 & 197.44 & \\
\hline
\end{tabular}

\section{Conclusions}

(1) With the increase of well spacing, the recovery degree increases slowly over time. And it costs less time to reach the maximum recovery degree when well spacing becomes gets smaller.

(2) In order to determine the reasonable well spacing scope of different reservoir, the concept of pseudo oil production rate is introduced, which refers the average annual oil production rate per unit area. Different pseudo oil production rate is corresponding to different scope of reasonable well 
spacing.

(3) According to the relationship curve between different well spacing and pseudo oil production rate, the reasonable well spacing scope of the reservoir in PL oilfield is calculated respectively when the pseudo oil production rate was $2 \%$, group lower MHZ is from $150 \mathrm{~m}$ to $200 \mathrm{~m}$, on the scope of reasonable well spacing for group upper GT is from $200 \mathrm{~m}$ to $250 \mathrm{~m}$, group lower GT is from $175 \mathrm{~m}$ to $225 \mathrm{~m}$.

(4) According to the scope of reasonable well spacing, determine the strategy of formation well pattern adjustment, predict the development effect by the numerical simulation model, finally it is concluded that recovery degree increased by $5.9 \%$, the north and the south area of single well increase $94200 \mathrm{~m} 3$ per well and $62300 \mathrm{~m} 3$ per well respectively than before, it significantly improved the oilfield development effect.

\section{Acknowledgement}

The research results of this paper is supported by the open fund of State Key Laboratory of Offshore Oil Exploitation (CCL2013RCPS0236GNN).

\section{Reference}

[1] Li jie, Li jijun, Yan jianian, determination of rational production-injection spacing by the degree of water flooding reserves in Gasikule oil field E13 reservoir, natural gas geoscience, 2012,23(5):956 958.

[2] Caoyumei, Licundong, Bao yanjun, determine reasonable injection-production well spacing to improve development effect of Wen 99 south block, China Petroleum and Chemical Standard and Quality, March:200.

[3] Zhou sibin, Du shengxiao, Qin fei, pressure propagation of ultra-low permeability reservoir and reasonable and reasonable well pattern research of Chang8 formation, petroleum geology and engineering, 2012,26(5):52 55.

[4] JIA Zhen qi, ZHAO Hui, WEN Feng gang, Determination of critical well spacing in the low permeability oil reservoirs, Daqing Petroleum Institute, 2006,30(1):104 105.

[5] Ji wei, Lu yuan, Yi xiangyi, the study of accommodation of injection-production pattern for chang62 reservoir ST2 borefield, zhengjing oilfield, petroleum geology and engineerin2009,23(5):50 53g.

[6] WANG Duan ping, SHI Dian hai, The main challenges and the reasonable well spacing for the development of low permeability sandstone reservoirs, Petroleum exploration and development, 2003,30(1):87 89.

[7] Creties Jenkins, Shahin Al-Sharif, Randy Harris. Forty Years of Improved Oil Recovery:

Lessons from Low-Permeability Turbidites of the East Wilmington Field[J]. SPE 92036.

[8] Saad Matar, Fahad AL-Medhadi, David Meadows. A Full Field Simulation Model of a Giant Cabonate Reservoir in Kuwait, Middle East Oil Show, 9-12 June, Bahrain.

[9] Wang quanlin, Chai shichao, Cheng zili, determination of reasonable well spacing in low permeability reservoir based on two phase flow, journal of northeast petroleum university, 2012, 36(4):45 48. 
[10] Zhang xuefen, Wang xinhai, Wang yu, rational well spacing stimulation model fractured reservoir, journal of Jianghan petroleum university institute, 2003, 25(4):98 99.

[11] YANG Xiao ping, TANG Jun, Determination of rational well spacing in low permeability sandstone reservoir by dynamic analysis, Special Oil and Gas Reservoirs, 2006, 13(6):64 66.

[12] WANG Jian-hua, NING Tao ,Reasonable injection-production well spacing determinate in low permeability reservoir, Inner Mongolia petrochemical industry, 2013, (4):22 24. 